University of Nebraska - Lincoln

DigitalCommons@University of Nebraska - Lincoln

2016

\title{
A Sediment-Based Reconstruction of Caribbean Effective Precipitation during the 'Little Ice Age' from Freshwater Pond, Barbuda
}

\author{
Michael J. Burn \\ University of the West Indies, michael.burn@uwimona.edu.jm \\ Jonathan Holmes \\ University College London \\ Lisa M. Kennedy \\ Virginia Polytechnic Institute and State University \\ Allison Bain \\ Université Laval \\ Jim D. Marshall \\ University of Liverpool
}

See next page for additional authors

Follow this and additional works at: https://digitalcommons.unl.edu/global

Part of the Biodiversity Commons, Biological and Physical Anthropology Commons, Geography

Commons, and the International and Area Studies Commons

Burn, Michael J.; Holmes, Jonathan; Kennedy, Lisa M.; Bain, Allison; Marshall, Jim D.; and Perdikaris, Sophia, "A Sediment-Based Reconstruction of Caribbean Effective Precipitation during the 'Little Ice Age' from Freshwater Pond, Barbuda" (2016). Global Studies Papers \& Publications. 14.

https://digitalcommons.unl.edu/global/14

This Article is brought to you for free and open access by the School of Global Integrative Studies at DigitalCommons@University of Nebraska - Lincoln. It has been accepted for inclusion in Global Studies Papers \& Publications by an authorized administrator of DigitalCommons@University of Nebraska - Lincoln. 
Authors

Michael J. Burn, Jonathan Holmes, Lisa M. Kennedy, Allison Bain, Jim D. Marshall, and Sophia Perdikaris 
Published in The Holocene (2016) 26(8): 1,237-1,247. doi: 10.1177/0959683616638418

Copyright 2016, Sage. Used by permission.

\title{
A Sediment-Based Reconstruction of Caribbean Effective Precipitation during the 'Little Ice Age'
} from Freshwater Pond, Barbuda

\author{
Michael J. Burn, Jonathan Holmes, Lisa M. Kennedy, Allison Bain, Jim D. Marshall, and Sophia Perdikaris
}

\begin{abstract}
Contemporary climate dynamics of the circum-Caribbean Region are characterized by significant precipitation variability on interannual and interdecadal timescales controlled primarily by El Niño Southern Oscillation (ENSO) and the Atlantic Multidecadal Oscillation (AMO). However, our understanding of pre-industrial climate variability in the region is hampered by the sparse geographic distribution of paleoclimate archives. Here, we present a high-resolution reconstruction of effective precipitation for Barbuda since the mid-16th Century, based on biostratigraphic and stable isotope analyses of fossil ostracods and gastropods recovered from lake sediment cores from Freshwater Pond, the only freshwater lake on the island. We interpret episodic fluctuations in shell accumulation in the sediment record to represent changes in the balance between precipitation and evaporation during the Little Ice Age (LIA 1400-1850 CE) and Industrial (1850-present) periods. Comparisons between indices of reconstructed ENSO and AMO variability, the abundance of the freshwater gastropod Pyrgophorus parvulus, and the $\delta^{18} \mathrm{O}$ records from ostracod calcite suggest that the relative influence of ENSO and AMO on long-term rainfall patterns in Barbuda has changed over the last 400 years. Our findings are in agreement with other high-resolution paleoclimate studies that suggest that long-term changes in effective precipitation during the LIA were much more variable, temporally and spatially, than previously suggested.
\end{abstract}

Keywords: Barbuda, Caribbean, Effective precipitation, Drought, Ostracods, Gastropods, Stable isotopes, Late Holocene, Little Ice Age

\section{Introduction}

A suite of established paleoclimate reconstructions indicate that dry conditions prevailed across the Caribbean region during the so-called Little Ice Age (LIA; 1400-1850 CE). The evidence supporting the regional occurrence of aridity at that time includes the sedimentary titanium record from the Cariaco Basin (Haug et al., 2001) and positive $\delta^{18} \mathrm{O}$ excursions from microfossil calcite recovered from lake sediments from the Yucatan Peninsula (Hodell et al., 2005) and the Dominican Republic (Lane et al., 2011). Further, coral-based sea surface temperature (SST) reconstructions suggest a $\sim 2-3{ }^{\circ} \mathrm{C}$ cooling of Caribbean SSTs during the LIA (Winter and Christy, 2000; Haase-Schramm, 2003; Black et al., 2007; Kilbourne et al., 2008), which resulted in less favorable thermodynamic conditions for convective rainfall and a more persistent southerly position of the Intertropical Convergence Zone (ITCZ).

However, the recent publication of new high-resolution precipitation reconstructions (Fensterer et al., 2012; Kennett et al., 2012; Burn and Palmer, 2014) has challenged the occurrence of a uniformly dry LIA across the circum-Caribbean Region, proposing instead that changes in the balance between precipitation and evaporation were far more variable, temporally and spatially. High-resolution core scans of the sediment geochemistry of a mangrove lagoon in southern Jamaica provide evidence for alternating episodes of rainfall and drought on interannual and interdecadal timescales during the LIA (Burn and Palmer, 2014). Similar patterns of variability are inferred from rainfall reconstructions from speleothem records in Belize (Kennett et al., 2012) and Cuba (Fensterer et al., 2012) as well as from coastal records of hurricane activity (Van Hengstum et al., 2014; Burn and Palmer, 2015) that suggest that the magnitude and frequency of tropical cyclones, which contribute significantly to regional rainfall, was highly variable during the LIA. Taken together, recent evidence suggests that the LIA climate was not uniformly dry; instead, rainfall patterns were characterized by a greater amplitude of variability, particularly when compared with those of the Medieval Climate Anomaly ( 1200-1400 CE) and the most recent period of centennial warming during the Industrial Period
( 1850 CE-present). To shed further light on the hydrological variability in the Caribbean during the LIA, we present a reconstruction of effective rainfall (i.e. precipitation minus evaporation) derived from biostratigraphic and stable isotope analyses of calcareous microfossils recovered from lake sediments in Barbuda, a small island in the Lesser Antilles.

\section{Background}

Site Description

Barbuda is a small $\left(174 \mathrm{~km}^{2}\right)$, low-lying limestone island of the Lesser Antilles island arc (Figure 1; Brasier and Donahue, 1985), which separates the tropical Atlantic Ocean from the Caribbean Sea. Barbuda's maximum average elevation of $\sim 30 \mathrm{~m}$ corresponds to a massive limestone plateau of Pliocene age known as 'The Highlands,' which occupies the southeast segment of the Island. The plateau is bounded by abandoned sea cliffs to the north and east and by alternating late-Pleistocene consolidated beach ridge and lagoon deposits to the west and south, which form the Codrington Limestone

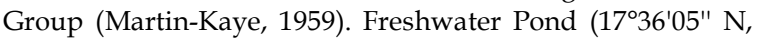
$61^{\circ} 47^{\prime} 28^{\prime \prime} \mathrm{W} ; \sim 6 \mathrm{~m}$ asl) is a permanent inland fresh-brackish water lake which is closed hydrologically and situated on the Codrington Limestone Group (Figure 1). Its late-Holocene origin is thought to be the result of rising eustatic sea level that reached its present-day maximum level ca. 3,000 years BP (Fairbanks, 1989), and the subsequent development of a rainfall-derived freshwater lens, which rests above the underlying salt water table (Brasier and Donahue, 1985). Consequently, the pond is very sensitive to precipitation variability

Burn: University of the West Indies, Kingston, Jamaica; corresponding author, michael.burn@uwimona.edu.jm Holmes: University College London, London, England, UK Kennedy: Virginia Tech, Blacksburg, Virginia, USA

Bain: Université Laval, Québec City, Québec, Canada Marshall: University of Liverpool, Liverpool, England, UK Perdikaris: Brooklyn College, New York, New York, USA Received Nov 2, 2015; revised manuscript accepted Jan 25, 2016. 
on multiple timescales (Stoddart et al., 1973). Indeed, lake levels vary markedly throughout the year in response to distinct seasonal changes in precipitation. During the boreal summer wet season the lake freshens and increases in size, on occasion almost trebling its surface area. Water salinity measurements performed in August and October 1970 (5.96\%o and 0.9\%; Stoddart et al., 1973) revealed fresh to slightly brackish conditions. Conversely, during the winter dry season Freshwater Pond contracts and evaporative concentration of the water body creates a brackish sedimentary environment (Stoddart et al., 1973). Thus, the pond may be characterized as an oligomesohaline system in which the marl substrate is dominated by the alga Chara sp. that supports abundant populations of calcareous fresh- to brackish-water ostracods and gastropods. A rare inland mangrove forest comprising extensive stands of Rhizophora mangle (red mangrove) with Conocarpus erectus (buttonwood) and Laguncularia racemosa (white mangrove) fringes the pond. This mangrove ecosystem may be a relic of a more extensive forest that was connected previously to the Caribbean Sea (Stoddart et al., 1973).

\section{Climate}

Barbuda experiences a seasonal sub-tropical maritime climate with distinct wet and dry seasons that occur during the boreal summer (May-October) and winter (NovemberApril), respectively. Temperatures remain relatively constant with an annual average of $\sim 27^{\circ} \mathrm{C}$ and range of $2-7^{\circ} \mathrm{C}$. Rainfall in Barbuda is relatively low for the region owing to the lowlying topography and lack of orographic rainfall. The island's easterly location within the Caribbean is rarely influenced by cold-front precipitation, which generally affects only the Northwest Caribbean. Between 1908 and 1960, average rainfall was $990 \mathrm{~mm}$ per annum ranging from 556-1,722 mm (Stoddart et al., 1973). Precipitation is generally controlled by the interplay between thermodynamic processes associated with sea surface temperature variability and dynamic processes associated with regional wind shear, which varies in response to the seasonal and interannual migration of the Intertropical Convergence Zone (ITCZ), the North Atlantic Subtropical High (NAH) and the Caribbean Low Level Jet (CLLJ; Enfield and Alfaro, 1999; Giannini et al., 2001; Cook and Vizy, 2010; Taylor et al., 2011). These processes also influence tropical cyclone activity, which contributes significantly to average annual rainfall in the region (Rodgers et al., 2001). Such activity is restricted to the boreal summer during which warm tropical Atlantic sea surface temperatures and the proximity of the Intertropical Convergence Zone (ITCZ) combine to provide a favorable environment for cyclone genesis.

Interannual and multidecadal variability in Caribbean rainfall patterns is controlled by a combination of El Niño Southern Oscillation (ENSO), the Atlantic Multidecadal Oscillation (AMO; Klotzbach, 2011; Winter et al., 2011) and the North Atlantic Oscillation (NAO; Wang, 2007; Cook and Vizy, 2010; Gouirand et al., 2012) the dynamics of which are described comprehensively elsewhere (Burn and Palmer, 2014).

The AMO is an index of North Atlantic sea surface temperature (SST) variability on multidecadal timescales with alternating warm and cold phases over periods of 65-70 years (Schlesinger and Ramankutty, 1994). It has been shown to have a widespread influence on climatic phenomena including tropical Atlantic hurricane activity (Goldenberg et al., 2001; Klotzbach, 2011) and precipitation in Africa (Folland et al., 1986), the Caribbean (Stephenson et al., 2014) and North America (Enfield, 2001). The oscillations are clearly recorded

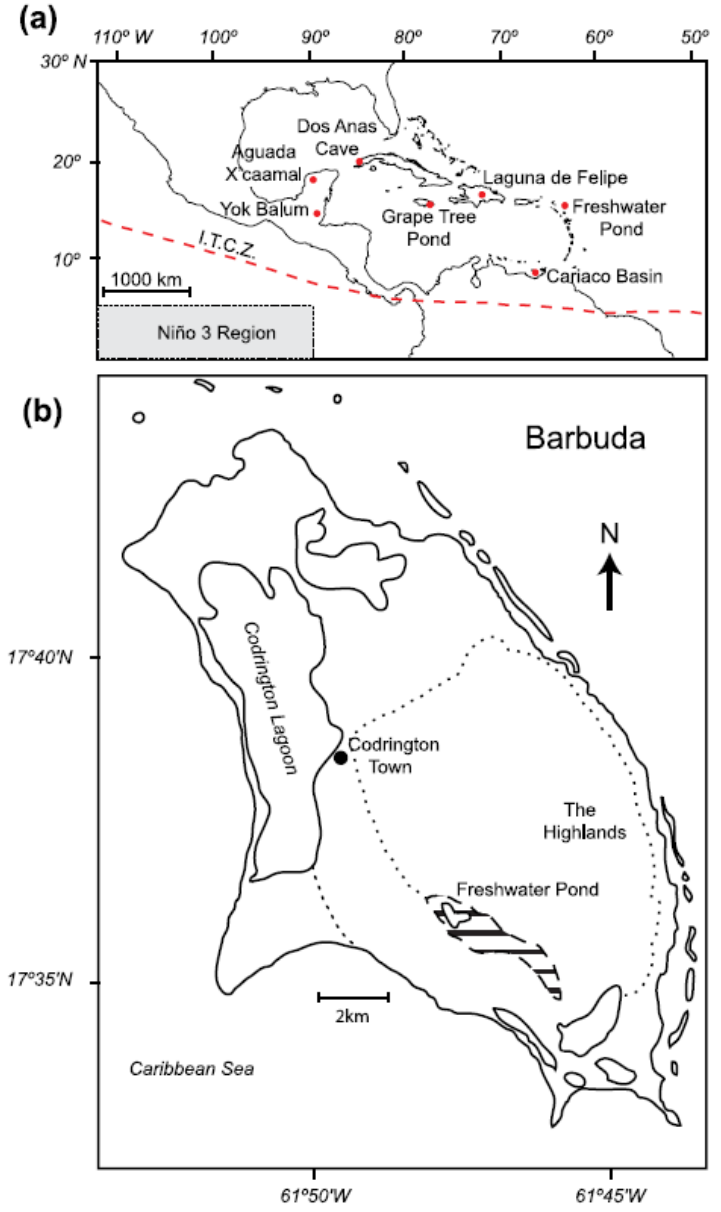

Figure 1. (a) Map of the circum-Caribbean region and the sites discussed in the text. From left to right: Yok-Balum Cave, Belize (Kennett et al., 2012); Aguada X'caamal, Yucatan Peninsula Mexico (Hodell et al., 2005); Dos Anas Cave, Cuba (Fensterer et al., 2012); Grape Tree Pond, Jamaica (Burn and Palmer, 2014); Laguna de Felipe, Dominican Republic (Lane et al., 2011); Cariaco Basin (Haug et al., 2001); Freshwater Pond, Barbuda. (b) Map of Barbuda showing the study site Freshwater Pond. The area represented by horizontal lines shows the maximum extent of the Pond during wetter periods.

in annual resolution coral-based SST (Hetzinger et al., 2008; Kilbourne et al., 2008b; Vásquez-Bedoya et al., 2012) and speleotherm-based precipitation (Winter et al., 2011; Fensterer et al., 2013) reconstructions for the Caribbean Region. Although the causes of AMO variability are poorly understood, it appears to be related to variations in the Atlantic Meridional Overturning Circulation (AMOC; Knight, 2005; Hodson et al., 2009) which may, in turn, be forced by external factors including solar and volcanic activity (Cubasch et al., 1997), anthropogenic aerosol concentrations (Kwiatkowski et al., 2013), or by the internal variability of AMOC (Knight, 2009; Knudsen et al., 2011) or indeed a combination of external and internal factors (Knudsen et al., 2014).

\section{Methodology}

Water samples

Samples of rainwater, lake water and shallow groundwater were collected on several occasions between April and 
October 2013 and analyzed to assist with interpretation of the carbonate isotope data. Some additional 'spot samples' were collected in May 2012. Surface waters and shallow groundwater samples were collected by completely filling $50-\mathrm{ml}$ polyethylene bottles, which were then sealed with electrical tape to minimize the risk of evaporative loss. Rainwater samples from May 2012 were collected in 50-ml polyethylene bottles using a funnel, whereas those from 2013 were integrated samples of total monthly rainfall collected in a specially-adapted rainfall collector following IAEA protocols (IAEA http:/ / wwwnaweb.iaea.org/napc/ih/documents/userupdate/sampling. pdf [accessed June 22, 2012]).

\section{Core recovery and chronology}

Three sediment cores (FP1-3) were recovered within a few meters of each other from Freshwater Pond through $\sim 1 \mathrm{~m}$ of water using a Colinvaux-Vohnout drop-hammer modified piston corer (Colinvaux et al., 1999). Core FP2 was extruded into 1 -cm slices in the field and stored at $4^{\circ} \mathrm{C}$ in the lab. Samples were dried for 1 hour at $60{ }^{\circ} \mathrm{C}$ to establish water content and analyzed for loss-on-ignition at $550^{\circ} \mathrm{C}$ and $950^{\circ} \mathrm{C}$ for organic matter and carbonate content, respectively (Dean Jr., 1974).

The sediment core chronology is based on four accelerator mass spectrometry (AMS) ${ }^{14} \mathrm{C}$ dates $( \pm 2 \sigma)$ on well-preserved and identifiable achenes of the oligo-meso haline species widgeongrass (Ruppia maritima), which can also tolerate extended periods of hypersalinity (Kantrud, 1991). Comparisons of the ${ }^{14} \mathrm{C}$ content of wood fragments and Ruppia achenes from the same level in a sediment core from the Island of Saint Martin (Lesser Antilles) did not reveal any significant reservoir effect (Bertran et al., 2004; Malaize et al., 2011). Plant macrofossils were treated using a base-acid-base treatment at the Scottish Universities Environmental Research Center (SUERC), East Kilbride, Scotland and the National Ocean Sciences Accelerator Mass Spectrometry Facility (NOSAMS) at Woods Hole Oceanographic Institution, USA. Given the low abundance of Ruppia maritima achenes within the sediment record, it was not possible to measure the $\delta^{13} \mathrm{C}$ ratio independently. Thus, an estimated $\delta^{13} \mathrm{C}$ value of $-15 \%$ was applied to normalize the uncorrected ${ }^{14} \mathrm{C}$ date, the value being based on $\delta^{13} \mathrm{C}$ measurements of Ruppia achenes growing in oligo-mesohaline water environments (Wozniak et al., 2006). An age-depth model was constructed using a linear interpolation fitted through four calibrated radiocarbon dates using Clam 2.1 (Blaauw, 2010). Radiocarbon dates were calibrated using the online software package OxCal 4.1 (Ramsey, 2001) and IntCal09 (Reimer et al., 2011). Data points are weighted according to the calibrated probabilities and all dates are reported in calibrated calendar years CE ( $2 \sigma$ error ranges).

\section{Faunal analyses}

$2 \mathrm{~cm}^{3}$ of sediment material was taken from each of the extruded $1 \mathrm{~cm}$ slices from core FP2 and gently washed with distilled water using a $63 \mu \mathrm{m}$ sieve to remove the fine fraction. The coarse fraction was dried overnight in an oven at $40^{\circ} \mathrm{C}$. Ostracod valves, gastropod shells and plant macrofossils were isolated and picked from the coarse fraction using a fine nylon brush under a low power $(20 \times)$ binocular microscope under incident light and identified. Taxonomic information about the ostracod species found came from the following sources: Martens \& Behen (1994), Broodbakker (1982, 1983a, b, c, 1984a, b,), Furtos (1934, 1936, 1938) and Keyser (1976). Ecological interpretations of the ostracod assemblages were based on the work of Holmes (1997), Keyser and Schöning (2000) and Pérez et al. (2010) and those of the gastropods based on McKillop and Harrison (1982) and Smith and Brousseau (1996). All gastropod shells and up to 250 individual adult ostracod valves were picked from each sample and stored on micropalaeontological slides. The presence and absence of pre-adult molts was assessed qualitatively to determine the extent to which the assemblages remained in situ. Only valves that were sufficiently whole to permit identification were picked.

\section{Stable isotopes}

Stable isotopes of oxygen and hydrogen in water samples were measured at the 'Lifer' stable isotope laboratory, University of Liverpool. Isotope ratios were determined simultaneously using a 'Picarro' WS-CRDS system and results are the average of at least 8 sequential injections of $2 \mu \mathrm{L}$ of water. Results were normalized to international standards using the SMOW/SLAP scale and verified by analysis of GISP as an unknown. Analytical precision was better than $0.08 \%$ for $\delta^{18} \mathrm{O}$ and $0.40 \%$ for $\delta D$.

Individual ostracod valves were selected from the $1 \mathrm{~cm}$ stratigraphic sediment sections from core FP2. Individual valves of adult specimens of the ostracod Heterocypris punctata were picked from the coarse fraction using a fine paint brush under a low-power binocular microscope. Prior to isotope analysis, ostracod valves were cleaned using a fine brush and then allowed to dry. Valves were then checked for impurities using a binocular microscope. Multiple-valve (5 valves for the majority of core levels) samples were analyzed using a ThermoFinnigan Delta Plus XP mass spectrometer connected to a GasBench. Oxygen-isotope values are reported in standard delta notation relative to the VPDB (Vienna Pee Dee belemnite) standard, with uncertainties of $0.09 \%$ for $\delta^{13} \mathrm{C}$ and $0.20 \%$ for $\delta^{18} \mathrm{O}(1 \sigma)$, at the Bloomsbury Environmental Isotope Facility (BEIF), University College London.

\section{Results}

Water isotopes

The spring/well waters range from about -2 to $-4.5 \%$ VSMOW (Vienna Standard Mean Ocean Water) for $\delta^{18} \mathrm{O}$ and -8 to $-28 \%$ for $\delta \mathrm{D}$ and are described by the relationship $\delta \mathrm{D}=7 \times$ $\delta^{18} \mathrm{O}+2.8$ (Figure 2). The linear regression line for these waters plots slightly to the right of that of the Global Meteoric Water Line (GMWL), which is described by the equation $\delta \mathrm{D}=8 \times \delta^{18} \mathrm{O}$ +10 . Further, the spring and well waters are, with one exception, distinctly more negative than the Freshwater Pond surface waters, of which the latter vary from $\sim+0.5$ to $+7.5 \%$ for $\delta^{18} \mathrm{O}$ and +2 and $+36 \%$ for $\delta \mathrm{D}$ and are described by the relationship $\delta \mathrm{D}=5 \times \delta^{18} \mathrm{O}-0.6$. The linear regression line for the lake waters has a significantly lower gradient than those of the GMWL and local ground water samples. The monthly-integrated precipitation samples fall reasonably close to the interception of the regression lines describing the spring/well and surface waters with the exception of the May 2013 sample and the two spot samples, which were all more positive.

\section{Sediment description and chronology}

The Freshwater Pond sediment core is composed of basal greenish-gray clays $(84-50 \mathrm{~cm})$ underlying $50 \mathrm{~cm}$ of uniform authigenic carbonate (marl) sediments rich in calcareous micro- and macrofossils including fresh- to brackish-water 


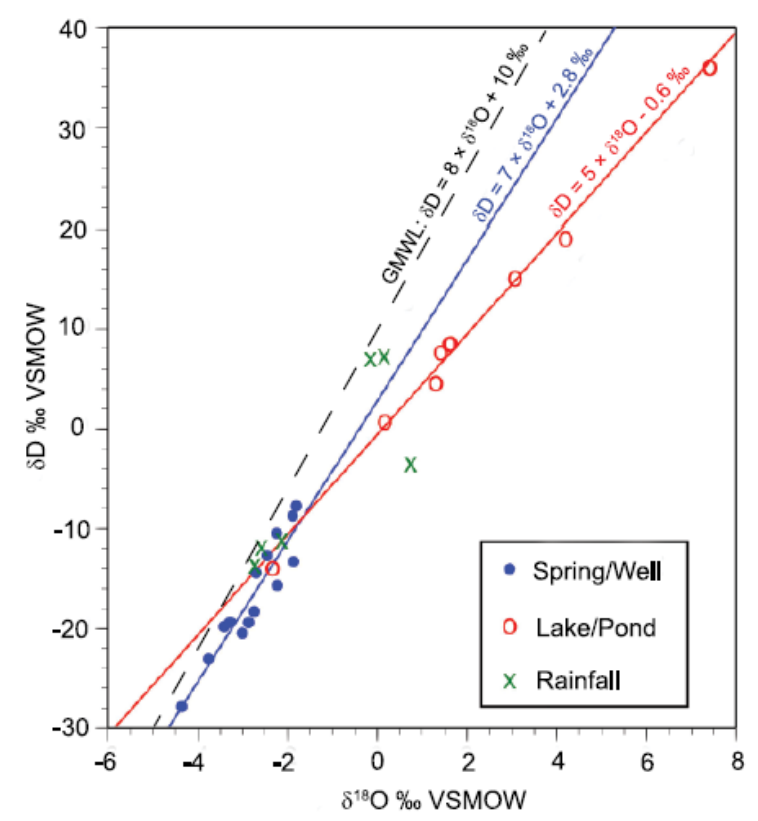

Figure 2. Plot of the stable isotope composition of ground water, precipitation and lake water in Barbuda collected on several occasions in May 2012 and between April and October 2013. Note the linear least squares regression lines for spring and lake waters have a lower gradient and fall below that of the Global Meteoric Water Line (GMWL) suggesting evaporative enrichment of the collected samples. Groundwater and rainfall samples were recovered from man-made wells and rainfall collectors on the Highlands Plateau. Lake water samples were collected from Freshwater Pond.

ostracods, gastropods, charophyte oospores and incrustations (Figure 3). The lowermost $12 \mathrm{~cm}$ of the record contains trace amounts of plant detritus (mangrove leaves) as well as gravelsized fragments of indurated limestone most likely derived from the underlying limestone terrace. Numerous iron-rich red mottles characterize the basal clays at $72-50 \mathrm{~cm}$, above which a sharp transition marks the lower boundary of marl formation. This transition is evident in the loss-on-ignition analyses characterized by a sharp rise in carbonate content and a concomitant decrease in the residual content. Table 1 presents the results of AMS radiocarbon dating for this site. The two basal radiocarbon ages $(63-64 \mathrm{~cm}$ and $64-65 \mathrm{~cm})$ are consistent, showing the deposition of greenish-gray clays occurred sometime before $\sim 40$ cal yr BCE. Sediment accumulation increased significantly above the transition to authigenic marls $(50 \mathrm{~cm})$, the initial deposition of which occurred be-

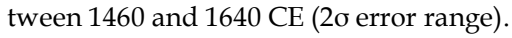

\section{Ostracod and gastropod assemblages}

Abundant and generally well-preserved ostracod and gastropod shells were found within the sediments. The assemblages contain adults and juveniles and therefore appear largely to be in situ, with only limited signs of reworking. The low-diversity assemblages contain at most five ostracod and two gastropod species, including one previously undocumented species. Here we restrict our interpretations to the ecological preferences of the most abundant ostracod and gastropod taxa, namely Heterocypris punctata, Chlamydotheca sp. and Pyrgophorus paroulus.
Heterocypris punctata (Keyser, 1975) is a nektobenthic ostracod, which is generally found in warm, shallow waters $(<1 \mathrm{~m})$ and is often associated with dense aquatic vegetation. Across the Caribbean it inhabits seasonally fluctuating coastal lagoons and prefers brackish-water conditions with a salinity range of $2-7 \%$ o (Keyser and Schoning, 2000); however, live specimens collected recently by the authors from Manatee Bay in Jamaica, suggest it has a wider tolerance range, including salinities up to $20 \%$. Ostracods in the genus Chlamydotheca (Saussure, 1838) are nektobenthic, prefer fresh water, and have a largely Neotropical distribution. Evidence from Jamaica suggests it prefers the shallow-water environments near the edges of lakes and ponds (Holmes, 1997) and is able to tolerate shallow and fluctuating water levels. The very large specimen found at Freshwater Pond has hitherto not been documented and is left in open nomenclature until living specimens can be obtained. Pyrgophorus paroulus (Guilding, 1828) has a circum-Caribbean distribution with documented specimens from Jamaica, Hispaniola, St. Lucia, Grenada, St. Vincent and the Grenadines, the U.S. Virgin Islands, Trinidad and Tobago, the Netherlands Antilles, and Venezuela (Harrison, 1984; Muchmore, 1993, Smith and Brousseau, 1996). It is a freshwater Hydrobiid gastropod that inhabits freshwater pools and ponds of varying sizes and depths with surface areas $<400 \mathrm{~m}^{2}$ (McKillopp and Harrison, 1982) and is often found in ephemeral and temporary ponds associated with episodes of heavy rainfall such as waterlogged banana drains and dasheen gutters. The species can tolerate brackish water conditions and has been collected from freshwater-fed mangrove forest ecosystems (Smith and Brousseau, 1996).

\section{Biostratigraphy and stable isotopes}

Calcareous microfossils and macrofossils including ostracod, gastropod and charophyte remains are abundant within the authigenic carbonate muds of the upper $50 \mathrm{~cm}$ of sediment core FP2; however, their abundance varies significantly throughout the sequence (Figure 4(a)). We sub-divided the sediment archive into five biostratigraphic units delimited by the absence of the freshwater gastropod Pyrgophorus parvulus at sediment depths of 5, 16, 30 and $42 \mathrm{~cm}$. Similar minima in the total sum of micro- and macro-fossils were observed at the same depths.

Two notable patterns emerged from the fossil ostracod and gastropod data. First, the relative abundance curves of ostracod remains (Figure 4(b)) suggest a gradual transition from a Chlamydotheca-dominated assemblage in the lower units (FP1-2) of the sediment profile to one dominated by Heterocypris punctata in the upper half (FP3-5). The progressive increase (decrease) in the relative abundances of $H$. punctata (Chlamydotheca) upcore is mirrored broadly by a rise in $\delta^{13} \mathrm{C}$ values. The second prominent pattern can be observed within the curve representing the total sum of micro- and macrofossils (Figure 4). Periodic pulses of shell accumulation occurred towards the center of each unit (FP1-5), and are separated by episodes during which the total abundance of micro- and macrofossils dropped significantly. This episodic variability in shell accumulation is mirrored broadly by the carbonate content of the sediment core, which co-varies with the total micro-and macro-fossil sum, a relationship that is particularly evident in units FP1 and FP2. A clear inverse relationship between the relative abundances of the freshwater gastropod $P$. parvulus and the brackish-water-tolerant ostracod H. punctata, is evident throughout the sediment record (Figure 4(b)). 

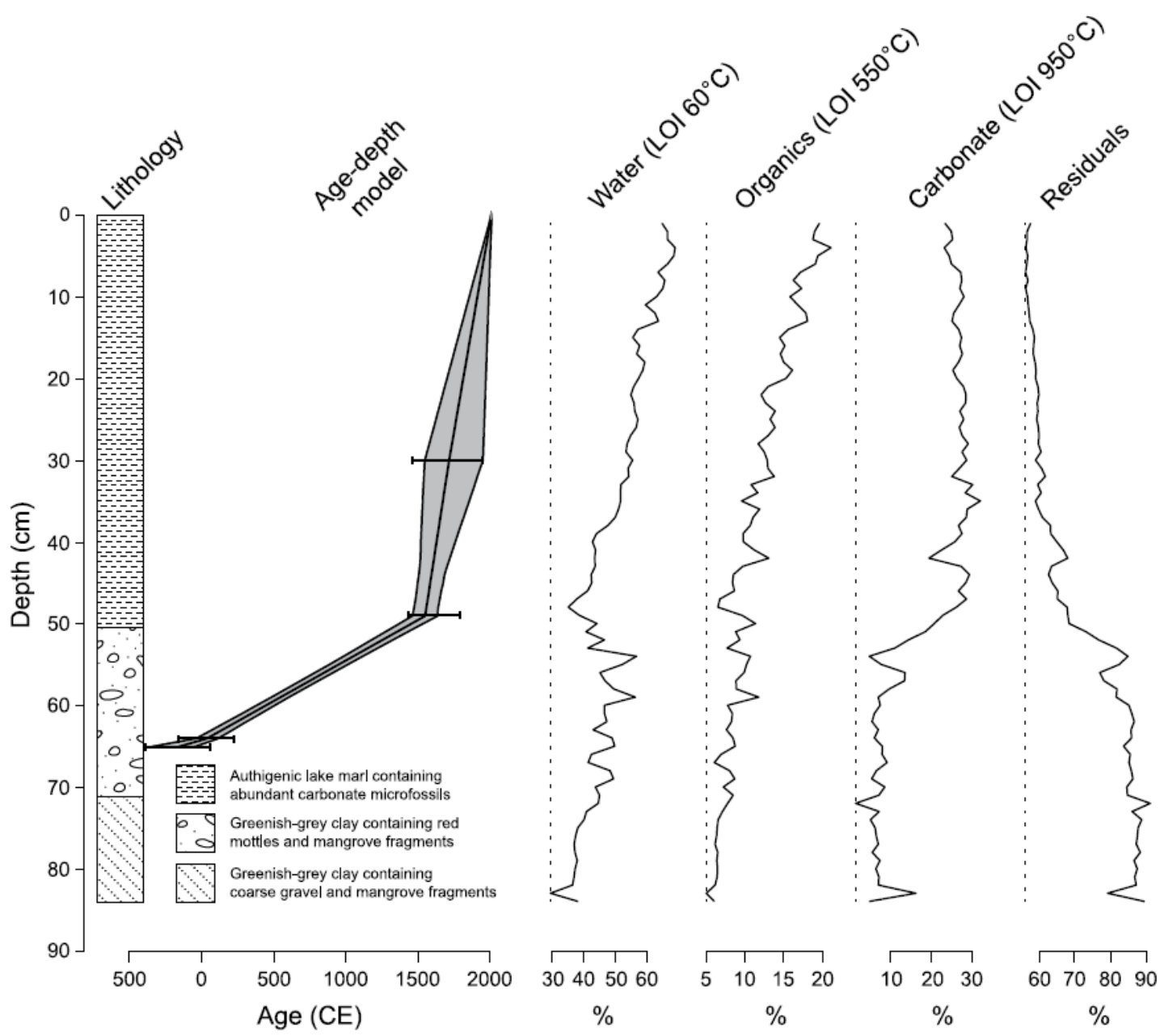

Figure 3. Sediment stratigraphy, age-depth model and the corresponding water, organic matter, carbonate and residual curves determined by loss-onignition for sediment core FP2 from Freshwater Pond, Barbuda.

Table 1. Radiocarbon dates for the last 1,200 calibrated years from the Freshwater Pond sediment record.

\begin{tabular}{|c|c|c|c|c|c|}
\hline Lab code & Depth $(\mathrm{cm})$ & $\delta^{13} \mathrm{C}(\% \circ)$ & Age ( ${ }^{14} \mathrm{C}$ yr BP) & $2 \sigma$ calibrated yr CE & Probability (\%) \\
\hline \multirow[t]{5}{*}{ SUERC-37169 } & $27-30$ & -15 (est.) & $242 \pm 30$ & 1936-1954 & 7.4 \\
\hline & & & & $1762-1802$ & 28.0 \\
\hline & & & & $1738-1751$ & 0.9 \\
\hline & & & & $1631-1682$ & 52.4 \\
\hline & & & & $1525-1558$ & 6.7 \\
\hline \multirow[t]{2}{*}{ SUERC-37170 } & $47-49$ & -15 (est.) & $347 \pm 30$ & $1463-1533$ & 39.1 \\
\hline & & & & $1536-1635$ & 55.8 \\
\hline \multirow{2}{*}{ OS-81963 } & $63-64$ & -25.17 & $1959 \pm 30$ & $103-122$ & 4.4 \\
\hline & & & & 40 BCE-88 & 91.0 \\
\hline \multirow[t]{3}{*}{ OS-81964 } & $64-65$ & -26.05 & $2121 \pm 40$ & 211-42 BCE & 83.1 \\
\hline & & & & 229-220 BCE & 0.9 \\
\hline & & & & 352-295 BCE & 11.4 \\
\hline
\end{tabular}

Dates marked in bold are more strongly weighed in the age-depth model.

Oxygen isotope values from the valves of $H$. punctata fluctuated between $\sim-0.5$ and $2.5 \%$ o for the sequence as a whole (Figure $4 \mathrm{~b}$ ). The core-top value of $+0.3 \%$ is consistent with its calcification in water with a $\delta^{18} \mathrm{O}$ value of about $+2.7 \%$ using the equation of Kim and O'Neil (1997), and assuming a calcification temperature of $30{ }^{\circ} \mathrm{C}$ and an offset from oxygen-isotope equilibrium of $+1 \%$ for $H$. punctata due to vital effects (Pérez et al., 2013). This is within the range of modern $\delta^{18} \mathrm{O}$ values for the water of Freshwater Pond (Figure 2).
The most positive excursions of $\sim 2.5 \%$ occur at 39,29 , and $16 \mathrm{~cm}$, broadly corresponding with the unit boundaries. The maximum $\delta^{18} \mathrm{O}$ value in the core occurs at $29 \mathrm{~cm}$ depth and equates to a lake water $\delta^{18} \mathrm{O}$ of $+5.2 \%$ o VSMOW, assuming water temperature of $30^{\circ} \mathrm{C}$, an estimate based on the average temperature range of waterbodies $\left(28-30^{\circ} \mathrm{C}\right)$ in similar climatic and environmental settings across the region (Burn and Palmer, 2014). The most negative values occur at 42,24 , and $11 \mathrm{~cm}$, of which the latter equates to a lake water $\delta^{18} \mathrm{O}$ of $+1.6 \%$ and $+1.2 \%$ assuming water temperatures of $30^{\circ} \mathrm{C}$ and 


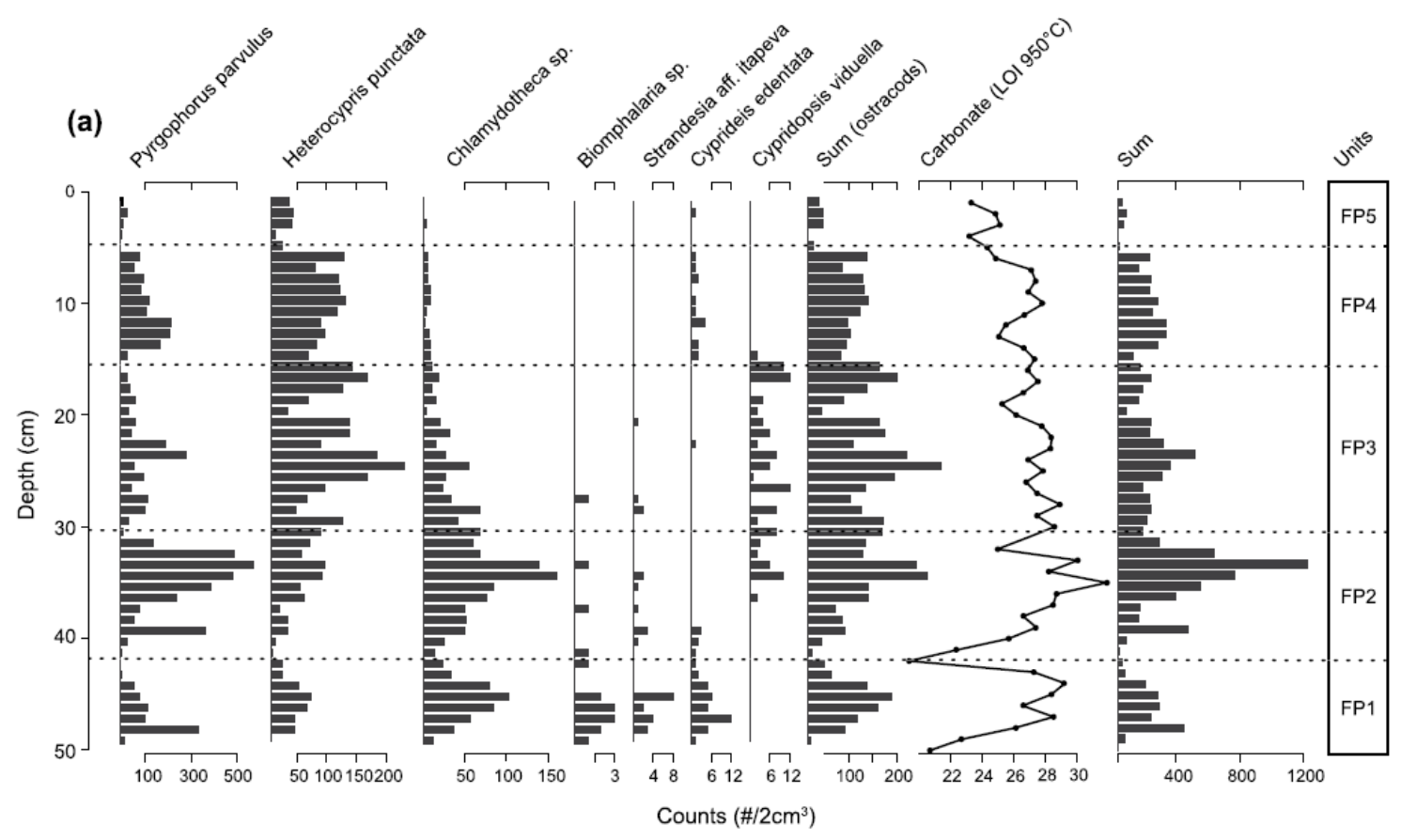

(b)

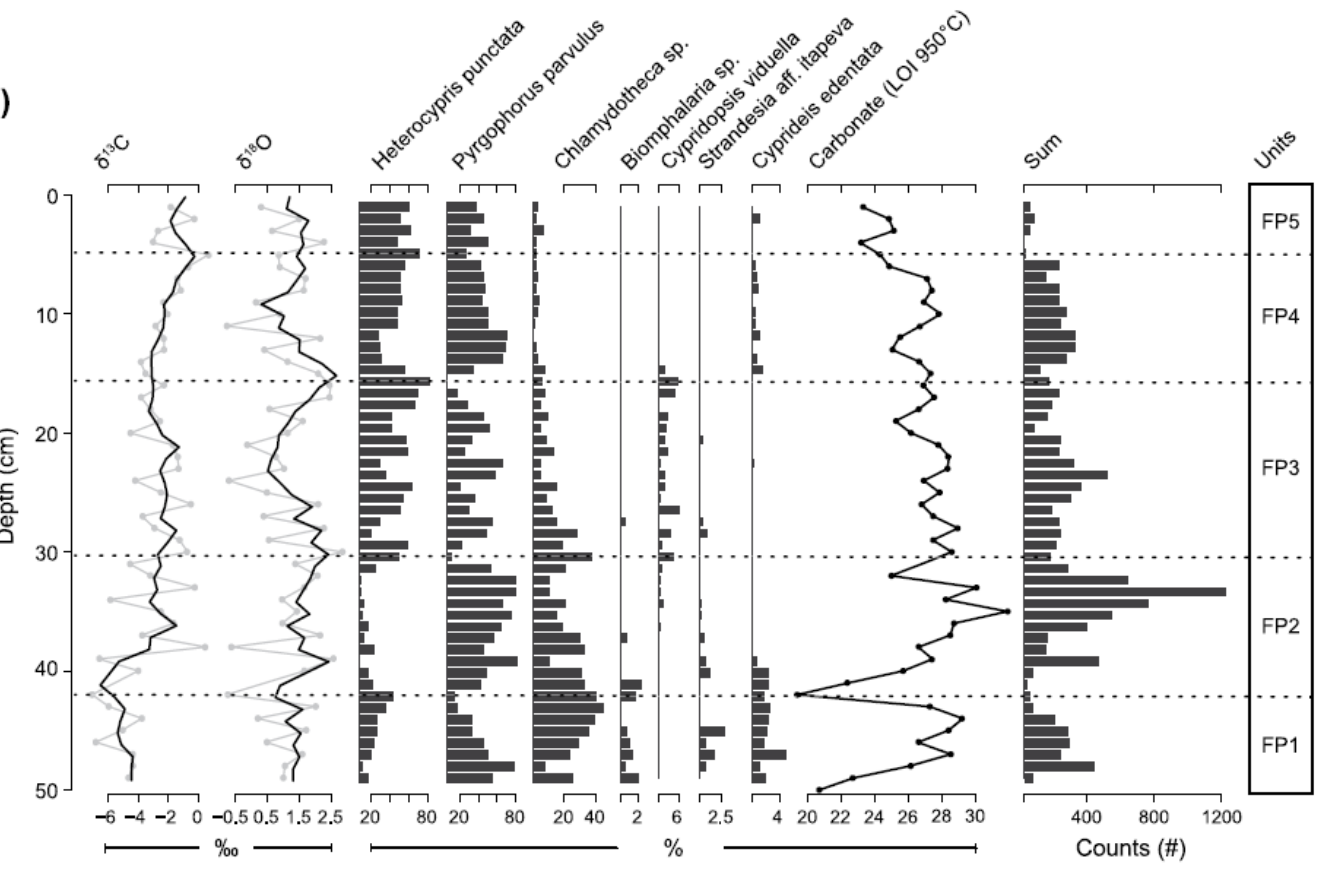

Figure 4. Ostracod and gastropod fauna of Freshwater Pond sediment core FP2 (a) absolute fossil counts (\#) for each taxon per $2 \mathrm{~cm}^{3}$ of sediment and the corresponding curves for the total sum of ostracod valves, carbonate content and the total sum for all micro-and macrofossil counts. The biostratigraphic units FP1-5 are delimited by boundaries defined by the absence of the freshwater gastropod Pyrgophorus parvulus. (b) Stable carbon and oxygen isotope measurements determined from fossil valves of the ostracod Heterocypris punctata compared with the relative abundance of selected ostracod and gastropod taxa, the carbonate content of sediment core FP2 and the total sum of all micro- and macrofossil counts. Light gray lines represent the original stable isotope measurements and the black line is a 5-point running mean of the isotope time series.

$28^{\circ} \mathrm{C}$, respectively. With the exception of units FP1 and FP2, the oxygen isotope record broadly follows the patterns in the abundance of $P$. paroulus, whereby positive (negative) excursions of oxygen isotope values coincide with periods of low (high) abundance of $P$. parvulus.

\section{Discussion}

\section{Stratigraphy and Chronology}

The genesis of Freshwater Pond occurred some 2,000 years $\mathrm{BP}$ with the deposition of the basal greenish-gray clays. 
The lake was probably connected to the Caribbean Sea at that time by means of the narrow channel extending southward from its southern margins. Greenish-gray clays are common constituents of coastal lagoon sediment profiles in the Caribbean region and are often emplaced immediately above the underlying carbonate platform prior to the accumulation of lagoonal sediments. They are thought to be formed by in situ crystallization of deeply weathered terrestrial material in lagoons of elevated salinity or on the shallow sea floor (Isphording, 1973). Mangrove fragments found preserved within the clay matrix provide evidence of an established mangrove forest that extended inland from the southern coast of Barbuda, which still thrives today despite the pond's isolation from the sea (>2 km). By 2,000 years BP, the rate of eustatic sea level rise had slowed and having reached contemporary levels, permitted the initial development of a freshwater lens that rested above the underlying saltwater table (Brasier and Donahue, 1985). Red mottles present within the clays from 70-50 $\mathrm{cm}$ suggest that lake levels changed significantly during this period, affecting redox conditions in the lake. Sediment accumulation rates remained low until the transition to the period of authigenic marl precipitation at $50 \mathrm{~cm}$ depth ( 1460-1640 CE; $2 \sigma$ error ranges), after which a sharp increase in the sedimentation rate occurred. The establishment of a more permanent water body at this time is supported by the presence of an abundant fresh-brackish water calcareous microfossil and macrofossil assemblage.

\section{Biostratigraphy and carbon isotopes}

Stable carbon isotopes measured from ostracod calcite are often interpreted as paleoproductivity indicators because ${ }^{12} \mathrm{C}$ is preferentially taken up by plants during photosynthesis, leaving lake-water Total Dissolved Inorganic Carbon (TDIC) with higher $\delta 13 C$ values (e.g. Holmes et al., 1997). As a result, positive excursions in $\delta^{13} \mathrm{C}$ may indicate periods of enhanced ecosystem productivity as ${ }^{12} \mathrm{C}$ is drawn down into the lakes' organic carbon store. However, changes in $\delta^{13} \mathrm{C}$ are also influenced by the interplay between the relative rates of plant respiration and decay and the exchange of $\mathrm{CO}_{2}$ between the atmosphere and the lake water. The former acts to reduce the $\delta^{13} \mathrm{C}$ value by releasing ${ }^{13} \mathrm{C}$-depleted $\mathrm{CO}_{2}\left(\delta^{13} \mathrm{C}=-30\right.$ to -10$)$ into the water body (Holmes et al., 1995). In contrast, in carbonate lakes, such as Freshwater Pond, that exhibit a high $\mathrm{pH}$ and are very well buffered, the pre-industrial atmosphere would have contributed $\mathrm{CO}_{2}$ with a ${ }^{13} \mathrm{C}$ value of $\sim-6.5 \%$ o to the lake-water TDIC (Gerber et al., 2003). In general, TDIC should have a $\delta^{13} C$ value $7.6 \%$ higher than that of the atmosphere at $28{ }^{\circ} \mathrm{C}$, assuming complete isotopic equilibrium exists between the two. Thus, assuming pre-industrial atmospheric $\mathrm{CO}_{2}$ had a $\delta^{13} \mathrm{C}$ value of about $-6.5 \%$, TDIC of Freshwater Pond would have had a $\delta^{13} \mathrm{C}$ value of $\sim+1.1 \%$. The range of values exhibited in sediments from Freshwater Pond are generally more negative, suggesting either that TDIC may not have been in complete isotopic equilibrium with the atmosphere and/or that plant respiration and decay were affecting the isotopic signature. With this in mind, we nevertheless interpret the longer-term trends in $\delta^{13} \mathrm{C}$ as a general indicator of ecosystem productivity.

The Freshwater Pond sediment record represents the establishment of a new fresh-brackish water ecosystem, thus the biological assemblages were not only influenced by environmental and climatic variability, but also by internal ecosystem dynamics associated with hydroseral succession. For example, the transition from a Chlamydotheca-dominated ostracod assemblage in units FP1\&2 to one dominated by Heterocypris punctata
(FP3-5) reflects not only a change from a fresh-to brackish water environment, but may also reflect a trend towards increased ecosystem productivity, an interpretation supported by the progressive increase in the $\delta^{13} \mathrm{C}$ values of ostracod calcite throughout the sequence. The low abundance of H. punctata in the lowermost units of the sediment record may relate to the early developmental stage of the lake.

Low levels of organic matter combined with negative excursions of $\delta^{13} \mathrm{C}$ suggest that photosynthetic activity within the lake was subdued at that time resulting in the low abundance of aquatic macrophytes, which, in turn, may have restricted the population expansion of $H$. punctata (Perez et al. 2010). Rising $\delta^{13} \mathrm{C}$ values and organic matter content, and the relative abundance of $H$. punctata, point to a transition to a more productive environment beginning around $1700 \mathrm{CE}$ (30 cm; FP3-5). The concomitant decline in the abundance of Chlamydotheca suggests that this species may have been outcompeted by H. punctata. The relative abundance of the gastropod Pyrgophorus parvulus, a predominantly freshwater species (McKillop and Harrison, 1982; Smith and Brousseau, 1996), provides further support for this interpretation; if the decline in Chlamydotheca had been caused by increased salinity levels alone, a parallel decline in the population of $P$. parvulus would be expected. The relative abundance of $P$. parvulus remains generally consistent throughout the sequence, highlighting the likelihood that the Chlamydotheca decline was caused by either increased competition with $H$. punctata or increased lake productivity, or a combination of both.

$P$. parvulus provides a robust and sensitive proxy for the changing balance of precipitation and evaporation because of its ability to thrive in both temporary and permanent water bodies in response to a rapid increase in rainfall (McKillop and Harrison, 1982). We interpret periodic pulses of shell accumulation recorded in each of the stratigraphic units (FP15) to reflect changing lake levels in response to changes in patterns of effective precipitation. We suggest that rapid increases in the abundance of $P$. paroulus and the total microand macro-fossil sum, reflect increases in effective rainfall that resulted in the expansion and freshening of Freshwater Pond. In contrast, their declining abundance indicated drier conditions that caused the lake to contract, thereby increasing salinity, a consequence of evaporative concentration. Because $H$. punctata exhibits greater tolerance of euryhaline conditions than P. paroulus, it would likely have outcompeted the gastropod during periods when evaporative concentration occurred in response to extended episodes of aridity. Thus, we interpret the inverse relationship between the relative abundances of H. punctata and P. parvulus on shorter timescales, to represent drier and wetter conditions, respectively (Figure 4).

Our proxy data indicate that the most severe period of aridity in our record occurred in Barbuda around 1600 CE (42 $\mathrm{cm}$ ) and is characterized by low micro-and macrofossil abundance and an associated drop in carbonate content (Figure 4). The combination of a drop in microfossil abundance, which included both fresh- and brackish-water-tolerant species, and the cessation of marl formation, would strongly suggest that the lake dried up entirely at that time. Other dry periods are inferred at around 1720 CE $(30 \mathrm{~cm}), 1800-1850 \mathrm{CE}(15-20 \mathrm{~cm})$, and during the last $\sim 30-40$ years (Unit FP5).

\section{Oxygen Isotopes}

The relationship between precipitation and the $\delta^{18} \mathrm{O}$ of lake water arises as a result of two additive processes. First, there is often a negative correlation between precipitation 


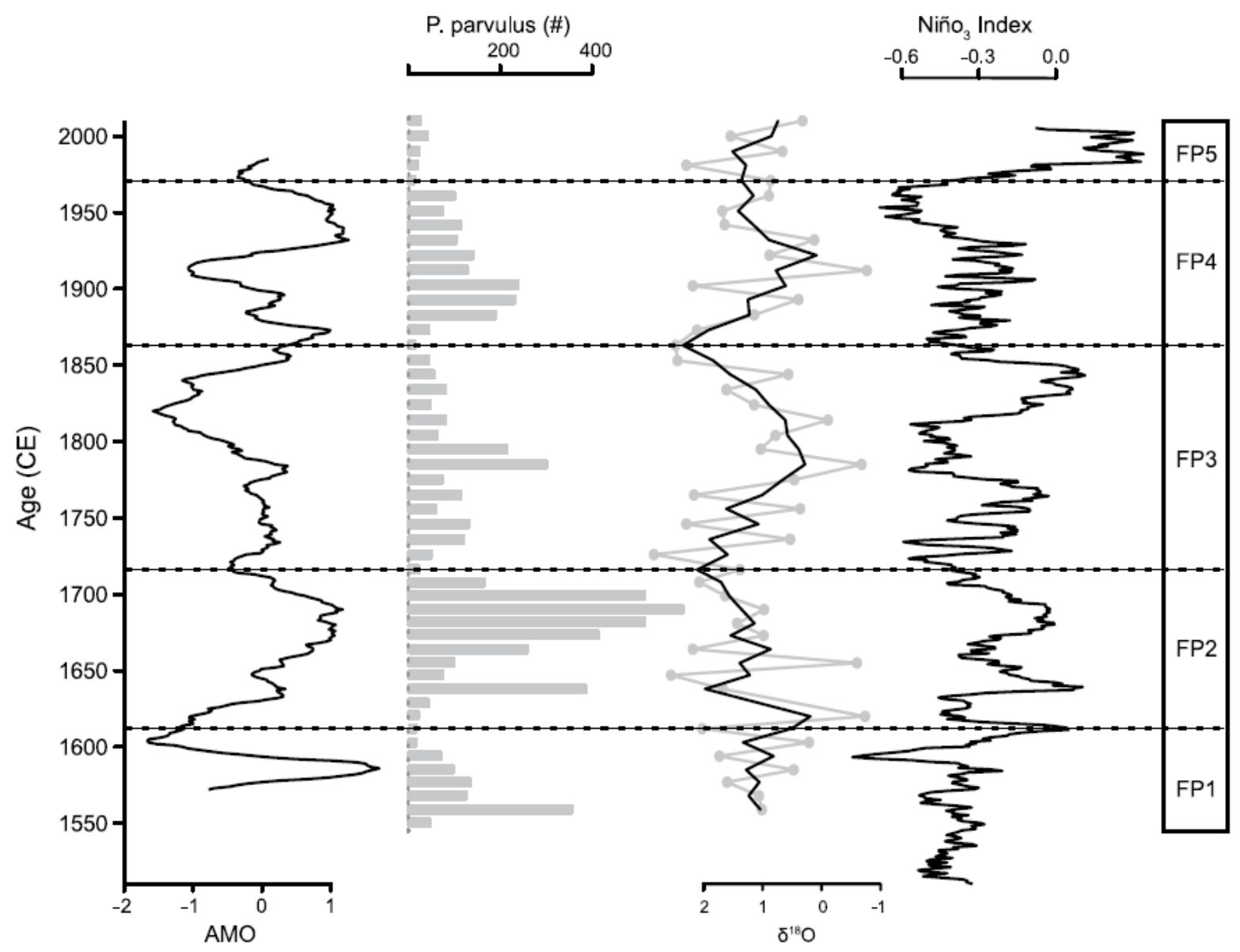

Figure 5. Comparisons between the tree-ring-based reconstructions of the Atlantic Multidecadal Oscillation (AMO) of Gray et al. (2004) and El Niño Southern Oscillation (ENSO) of Li et al. (2013) and counts of the freshwater gastropod Pyrgophorus parvulus (Guilding, 1828) and the oxygen isotope determinations of ostracod calcite of Heterocypris punctata (Keyser, 1975) for the period 1500 CE-present.

amount and $\delta^{18} \mathrm{O}$ value of precipitation $\left(\delta^{18} \mathrm{O}_{\mathrm{p}}\right)$ as a result Rayleigh distillation, which occurs during rain-out; this relationship represents the so-called 'amount effect' (Dansgaard, 1964). Thus, periods of increased rainfall are associated with lower $\delta^{18} \mathrm{O}_{\mathrm{p}}$ values. Second, the $\delta^{18} \mathrm{O}$ of surface water in lakes and ponds is often modified as a result of evaporation, during which water molecules containing lighter isotopes are lost preferentially, leaving the remaining waterbody relatively enriched in heavier isotopes. Enhanced evaporative enrichment occurs when effective moisture (P-E) and atmospheric humidity are low. Consequently, during dry intervals, reduced rainout produces precipitation with a relatively high $\delta^{18} \mathrm{O}_{\mathrm{p}}$ value and this value is further increased by kinetic fractionation during evaporative enrichment after the water has reached the ground surface. Secondary effects, determined by the source, transport paths, and rainout history of the air masses, all of which are linked to atmospheric circulation, may also influence the $\delta^{18} \mathrm{O}_{\mathrm{p}}$ value of rainfall, and hence lake water.

We argue that the oxygen isotopic composition of lake waters from Freshwater Pond is sensitive to the changing balance between lake water inputs (precipitation and groundwater) and evaporative loss. The $\delta^{18} \mathrm{O}$ and $\delta \mathrm{D}$ values of the contemporary lake waters are distinctly more positive than those of the rainfall and groundwater samples indicating a marked kinetic fractionation due to evaporative enrichment (Figure 2). Further, the regression equation for the lake waters of Freshwater Pond $\left(\delta D=5 \times \delta^{18} \mathrm{O}-0.6\right)$ defines an evaporative line, which falls below the GMWL $\left(\delta D=8 \times \delta^{18} \mathrm{O}+10\right)$ and has a slope of about 5 . These values are consistent with those of other tropical lakes where evaporation is a dominant process including the lake waters of Wallywash Great Pond in Jamaica $\left(\delta D=5.5 \times \delta^{18} \mathrm{O}-0.06\right.$; Holmes et al., 1995), the combined waters of lakes Chichancanab and Petén Itzá on the Yucatan Peninsula in Mexico $\left(\delta \mathrm{D}=5 \times \delta^{18} \mathrm{O}-1.3\right.$; Hodell et al., 2012) and a suite of lakes in East Africa (Craig 1961). Given our contention that the isotopic composition of Freshwater Pond reflects changes in effective moisture and that lake waters are the dominant control on the oxygen isotopic composition of biogenic calcite in hydrologically closed lakes, we therefore interpret the $\delta^{18} \mathrm{O}$ of fossil ostracod calcite to be a proxy for effective precipitation.

The most positive excursions of $\delta^{18} \mathrm{O}$ of ostracod calcite in our sediment record are generally associated with episodes of low microfossil abundance (particularly P. parvulus), and so support our inference that these episodes represent periods of relative aridity (Figure $4(\mathrm{~b})$ ). These positive excursions equate to a lake water $\delta^{18} \mathrm{O}$ of $\sim+5 \%$ after correcting for vital 
effects, and exceed contemporary values for rainfall that fall between -3 and $+1 \%$ (Figure 2 ) and those of most of the collected pond waters (values of -2 to $+5 \%$ ) suggesting that the periods of low effective moisture were more extreme than today. In contrast, the wetter periods inferred from peaks in microfossil abundance at 32, 24, and $11 \mathrm{~cm}$ are associated with lower $\delta^{18} \mathrm{O}$ values $(\sim 1.5 \%)$, which lie within the range of the collected contemporary pond waters. The coincidence at $\sim 1600$ CE of low microfossil abundance, carbonate values and negative excursions of $\delta^{18} \mathrm{O}$ (Figures 4 and 5) is an exception and is likely explained by the desiccation of the lake at that time and the subsequent breakdown in the relationship between $\delta^{18} \mathrm{O}$ variability of ostracod calcite and changes in effective moisture.

\section{Climate variability in Barbuda during the Little Ice Age}

Our microfossil-based climate reconstruction suggests that the island of Barbuda experienced significant variability in effective rainfall over the past four centuries, a period that spans much of the so-called Little Ice Age ( 1400-1850 CE). This result supports the findings of a geochemical study of a sediment core from a mangrove lagoon in Jamaica, which shows not only that the climate of Jamaica was not uniformly dry during the LIA, but that it was also characterized by enhanced rainfall variability on multidecadal timescales (Burn and Palmer, 2014). Similar conclusions have been drawn from speleothem-based precipitation reconstructions for Cuba (Fensterer et al., 2013) and Belize (Kennett et al., 2012), which attest to the significant climate variability that occurred during the LIA across the Caribbean region. Importantly, these findings contradict those of other regional paleoclimate studies, which indicate that the LIA was manifested as an extended episode of aridity across the circum-Caribbean region (Haug et al., 2001; Hodell et al., 2005; Lane et al., 2011).

Recent studies on the modern climate dynamics of the Caribbean region suggest that ENSO and the AMO are the principal drivers of contemporary rainfall patterns (Giannini et al., 2001; Dunstone et al., 2013). To examine the influence of these modes of climate variability on the longer-term effective rainfall in Barbuda, we compared the abundance of Pyrgophorus parvulus with the oxygen isotope record from Freshwater Pond and high resolution tree-ring-based reconstructions of the AMO (Gray et al., 2004) and ENSO (Li et al., 2013; Figure 5 ). We found a remarkable correspondence between the abundance of $P$. parvulus and the AMO reconstruction between about 1550 and $1850 \mathrm{CE}$, which suggests that extended episodes of aridity may be explained by suppressed SSTs in the tropical Atlantic. Similarly, periods of increased effective moisture were often associated with warmer Atlantic SSTs. The covariance between these two proxy records not only supports the integrity of the tree-ring based SST reconstruction for the Atlantic Region, but also suggests that sea surface temperature variability in the Atlantic has had a dominant influence on rainfall patterns in Barbuda at least between 1550 and $1850 \mathrm{CE}$ during the period associated with the LIA. The close correspondence between Atlantic SST and rainfall patterns may be explained intuitively because Barbuda is located very close to the center of AMO activity in the Tropical Atlantic, which during the wet season directly affects tropospheric stability and in turn precipitation and tropical cyclone activity.

Comparison of our microfossil data with the ENSO reconstruction of Li et al. (2013) for the past five centuries suggests that ENSO has also had a strong influence on rainfall patterns in Barbuda, particularly since about 1700 CE. Episodes of stronger El Niño-like activity occurred during the periods $1720-1775,1820-1850$, and 1975-2010 and were associated with drier conditions in our study as represented by the low abundance of $P$. parvulus and more positive $\delta^{18} \mathrm{O}$ values. In contrast, inferred wetter periods between 1775-1800 CE and during the late $19^{\text {th }}$ century correspond with La Niña-like conditions in the tropical Pacific. Given that contemporary rainfall patterns in the region are strongly controlled by the interplay between ENSO and the AMO, we interpret the changing long-term rainfall patterns represented in the Barbuda record to also reflect the relative influences of these regional-scale climatic phenomena. The Freshwater Pond sediment record provides strong evidence that sea surface temperatures in the Atlantic were the overriding control on rainfall patterns in Barbuda between about 1550 and $1720 \mathrm{CE}$. From 1720-1860 CE, ENSO appears to have exerted some additional influence and to have combined with the AMO to reinforce drier conditions between 1720-1775 and 1820-1850 and wetter conditions from 1775-1800. The relationship between the AMO and rainfall patterns in Barbuda appears to break down during the industrial era, possibly because of the increased influence of ENSO at that time. Thus, long-term patterns of effective rainfall in Barbuda appear to result from the combined and temporally variable influence of both Atlantic and Pacific modes of climate variability.

\section{Acknowledgements}

The authors thank Dr. Reg Murphy of the National Parks Antigua and Barbuda, the Barbuda Council, Anne-Marie Faucher, Allison Leblanc, Eve Tycenski and Emily Lin for field and laboratory support and Professor Chris Paul for identifying the gastropod Pyrgophorus parvulus. We thank Mark Brenner and an anonymous reviewer for their comments and insights, which helped improve the manuscript substantially. We appreciate the support to M. Burn from the UWI New Initiative Programme and UWI Study and Travel Grant. This material is based upon work supported by the National Science Foundation under Grant No. 0851727 to S. Perdikaris and by a grant from the Natural Environment Research Council (Grant No. NE/K00610X/1) to J. Holmes, and by a grant to A. Bain from the Social Science and Humanities Research Council of Canada via the Research Development Initiatives program. Data will be made available from the NOAA's National Centers for Environmental Information (NCEI) (http://www.ncdc.noaa.gov/data-access/paleoclimatology-data/datasets).

\section{References}

Bertran P, Bonnissent D, Imbert D et al. (2004) Paléoclimat des Petites Antilles depuis 4000 ans BP: l'enregistrement de la lagune de Grand-Case à Saint-Martin. Comptes Rendus Geoscience 336: $1,501-1,510$.

Black DE, Abahazi MA, Thunell RC et al. (2007) An 8-century tropical Atlantic SST record from the Cariaco Basin: Baseline variability, twentieth-century warming, and Atlantic hurricane frequency. Paleoceanography 22: PA4204.

Brasier M and Donahue J (1985) Barbuda: An emerging reef and lagoon complex on the edge of the Lesser Antilles island arc. Journal of the Geological Society 142: 1,101-1,117.

Broodbakker NW (1982) Amsterdam expeditions to the West Indian Islands, report 20. The genus Heterocypris (Crustacea, Ostracoda) in the West Indies. Part 1. Taxonomic characteristics. Bijdragen tot de Dierkunde 52: 207-227.

Broodbakker NW (1983a) Amsterdam expeditions to the West Indian Island, report 24. The genus Heterocypris (Crustacea, Ostracoda) in the West Indies. Part II. Carapace length, ecology and zoogeography. Bijdragen tot de Dierkunde 53: 115-134.

Broodbakker NW (1983b) Amsterdam expeditions to the West Indian Islands, report 34 . The subfamily Candoninae (Crustacea, Ostracoda) in the West Indies. Bijdragen tot de Dierkunde 53: 287326. 
Broodbakker NW (1983c) Amsterdam expeditions to the West Indian Islands, report 35. The genus Strandesia and other Cypricercini (Crustacea, Ostracoda) in the West Indies. Part I. Taxonomy. Bijdragen tot de Dierkunde 53: 327-368.

Broodbakker NW (1984a) The distribution and zoogeography of freshwater Ostracoda (Crustacea) in the West Indies with emphasis on species inhabiting wells. Bijdragen tot de Dierkunde 54: 2550.

Broodbakker, NW (1984b) The genus Strandesia and other Cypricercini (Crustacea, Ostracoda) in the West Indies Part II. Carapace length, ecology and distribution of two Strandesia species. Bijdragen tot de Dierkunde 54: 1-14.

Burn MJ and Palmer SE (2014) Solar forcing of Caribbean drought events during the last millennium. Journal of Quaternary Science 29: 827-836.

Burn MJ and Palmer SE (2015) Atlantic hurricane activity during the last millennium. Scientific Reports 5: 12838.

Colinvaux PA, Oliveira PED and Moreno E (1999) Amazon: Pollen Manual and Atlas. Harwood Academic Publishers: London, UK

Cook KH and Vizy EK (2010) Hydrodynamics of the Caribbean lowlevel jet and its relationship to precipitation. Journal of Climate 23: 1,477-1,494.

Covich A (1976) Recent changes in molluscan species diversity of a large tropical lake (Lago de Peten, Guatemala). Limnology and Oceanography 21: 51-59.

Craig H (1961) Isotopic variations in meteoric waters. Science 133: 1702-1703

Cubasch U, Voss R, Hegerl GC et al. (1997) Simulation of the influence of solar radiation variations on the global climate with an ocean-atmosphere general circulation model. Climate Dynamics 13: 757-767.

Dansgaard W (1964) Stable isotopes in precipitation. Tellus A 16: 436468

Dean Jr W (1974) Determination of carbonate and organic matter in calcareous sediments and sedimentary rocks by loss on ignition: comparison with other methods. Journal of Sedimentary Research 44: 242-248.

Dunstone NJ, Smith DM, Booth BB et al. (2013) Anthropogenic aerosol forcing of Atlantic tropical storms. Nature Geoscience 6: 534539.

Enfield D (2001) The Atlantic multidecadal oscillation and its relation to rainfall and river flows in the continental US. Geophysical Research Letters 28: 2077-2080.

Enfield DB and Alfaro EJ (1999) The dependence of Caribbean rainfall on the interaction of the tropical Atlantic and Pacific Oceans. Journal of Climate 12: 2093-2103.

Fairbanks RG (1989) A 17,000-year glacio-eustatic sea level record: influence of glacial melting rates on the Younger Dryas event and deep-ocean circulation. Nature 342: 637-642.

Fensterer C, Scholz D, Hoffmann D et al. (2012) Cuban stalagmite suggests relationship between Caribbean precipitation and the Atlantic Multidecadal Oscillation during the past $1.3 \mathrm{ka}$. The Holocene 22: 1,405-1,412.

Fensterer C, Scholz D, Hoffmann DL et al. (2013) Millennial-scale climate variability during the last $12.5 \mathrm{ka}$ recorded in a Caribbean speleothem. Earth and Planetary Science Letters 361: 143-151.

Folland CK, Palmer TN and Parker DE (1986) Sahel rainfall and worldwide sea temperatures, 1901-85. Nature 320: 602-607.

Furtos NC (1934) Two new species of Cypretta from the Marquesas Islands and Florida with notes on the distribution of the species. Bulletin of the Bernice P. Bishop Museum 114: 279-286.

Furtos NC (1936) On the Ostracoda from the Cenotes of Yucatan and vicinity. Publications of the Carnegie Institutions of Washington 457: 89-115.

Furtos NC (1938) A new species of Cypridopsis from Yucatan. Publications of the Carnegie Institutions of Washington 491: 155-157.

Gerber S, Joos F, Brügger P et al. (2003) Constraining temperature variations over the last millennium by comparing simulated and observed atmospheric $\mathrm{CO}_{2}$. Climate Dynamics 20: 281-299.

Giannini A, Cane MA and Kushnir Y (2001) Interdecadal changes in the ENSO Teleconnection to the Caribbean Region and the North Atlantic Oscillation. Journal of Climate 14: 2,867-2,879.
Goldenberg SB, Landsea CW, Mestas-Nunez AM et al. (2001) The recent increase in Atlantic hurricane activity: Causes and implications. Science 293: 474-479.

Gouirand I, Jury MR and Sing B (2012) An analysis of low- and highfrequency summer climate variability around the Caribbean Antilles. Journal of Climate 25: 3,942-3,952.

Gray ST, Graumlich LJ, Betancourt JL et al. (2004) A tree-ring based reconstruction of the Atlantic Multidecadal Oscillation since 1567 A.D. Geophysical Research Letters 31: L12205.

Haase-Schramm A, Böhm F, Eisenhauer A et al. (2003) Sr/Ca ratios and oxygen isotopes from sclerosponges: Temperature history of the Caribbean mixed layer and thermocline during the Little Ice Age. Paleoceanography 18: 1073

Harrison AD (1984) Redescription of Pyrgophorus parvulus (Gastropoda: Hydrobiidae) from St. Vincent, St. Lucia, and Grenada, West Indies. Proceedings of the Academy of Natural Sciences of Philadelphia 136: 145-151.

Haug GH, Hughen KA, Sigman DM et al. (2001) Southward migration of the intertropical convergence zone through the Holocene. Science 293: 1,304-1,308.

Hetzinger S, Pfeiffer M, Dullo WC et al. (2008) Caribbean coral tracks Atlantic Multidecadal Oscillation and past hurricane activity. Geology 36: 11-14.

Hodell DA, Brenner M, Curtis JH et al. (2005) Climate change on the Yucatan Peninsula during the Little Ice Age. Quaternary Research 63: 109-121.

Hodell DA, Turchyn AV, Wiseman CJ et al. (2012) Late Glacial temperature and precipitation changes in the lowland Neotropics by tandem measurement of $\delta^{18} \mathrm{O}$ in biogenic carbonate and gypsum hydration water. Geochimica et Cosmochimica Acta 77: 352-368.

Hodson DLR, Sutton RT, Cassou C et al. (2009) Climate impacts of recent multidecadal changes in Atlantic Ocean Sea Surface Temperature: A multimodel comparison. Climate Dynamics 34: 1,041-1,058.

Holmes JA (1997) Recent non-marine Ostracoda from Jamaica, West Indies. Journal of Micropalaeontology 16: 137-143.

Holmes JA, Street-Perrott FA, Heaton THE et al. (1995) Chemical and isotopic composition of karstic lakes in Jamaica, West Indies. Hydrobiologia 312: 121-138.

Holmes JA, Street-Perrott FA, Allen MJ et al. (1997) Holocene palaeolimnology of Kajemamm Oasis, Northern Nigeria: An isotopic study of ostracodes, bulk carbonate and organic carbon. Journal of the Geological Society 154: 311-319.

Isphording WC (1973) Discussion of the occurrence and origin of sedimentary Palygorskite-Sepiolite deposits. Clays and Clay Minerals 21: 391-401.

Kantrud H (1991) Wigeongrass (Ruppia maritima): A literature review. Fish and Wildlife Research 10: 1-58.

Kennett DJ, Breitenbach SFM, Aquino VV et al. (2012) Development and disintegration of Maya political systems in response to climate change. Science 338: 788-791.

Keyser D (1975) Ostracoden aus den Mangrovegebieten Südwest-Florida (Crustacea: Ostracoda, Podocopa). Abhandlungen und Verhandlungen des Naturwissenschaftlichen Vereins zu Hamburg 18/19: 255-290

Keyser D (1976) Ecology and zoogeography of recent brackish-water Ostracoda (Crustacea) from South-west Florida. In: Löffler, H. and Danielopol DH (eds.), Aspects of Ecology and Zoogeography of Recent and Fossil Ostracoda. The Hague, D. W. Junk, 207-222.

Keyser D (1977) Brackwasser-Cytheracea aus Süd-Florida (Crust.: Ostracoda: Podocopa). Abhandlungen und Verhandlungen des Naturwissenschaftlichen Vereins zu Hamburg 20: 43-85.

Keyser D and Schöning C (2000) Holocene ostracoda (crustacea) from Bermuda. Senckenbergiana lethaea 80: 567-591.

Klie W (1939) Süßwasserostracoden aus Nordbrasilien. III. Die Gattungen Stenocypris und Dolerocypris. Zoologischer Anzeiger 128: 316-320.

Kilbourne KH, Quinn TM, Webb R et al. (2008) Paleoclimate proxy perspective on Caribbean climate since the year 1751: Evidence of cooler temperatures and multidecadal variability. Paleoceanography 23: PA3220. 
Klotzbach PJ (2011) The influence of El Niño-Southern Oscillation and the Atlantic Multidecadal Oscillation on Caribbean tropical cyclone activity. Journal of Climate 24: 721-731.

Knight JR (2005) A signature of persistent natural thermohaline circulation cycles in observed climate. Geophysical Research Letters 32: L20708.

Knight JR (2009) The Atlantic Multidecadal Oscillation Inferred from the forced climate response in coupled General Circulation Models. Journal of Climate 22: 1,610-1,625.

Knudsen MF, Seidenkrantz MS, Jacobsen BH et al. (2011) Tracking the Atlantic Multidecadal Oscillation through the last 8,000 years. Nature Communications 2: 178.

Knudsen MF, Jacobsen BH, Seidenkrantz MS et al. (2014) Evidence for external forcing of the Atlantic Multidecadal Oscillation since termination of the Little Ice Age. Nature Communications 5: 3323.

Kwiatkowski L, Cox PM, Economou T et al. (2013) Caribbean coral growth influenced by anthropogenic aerosol emissions. Nature Geoscience 6: 362-366

Lane CS, Horn SP, Orvis KH et al. (2011) Oxygen isotope evidence of Little Ice Age aridity on the Caribbean slope of the Cordillera Central, Dominican Republic. Quaternary Research 75: 461-470.

Li J, Xie SP, Cook ER et al. (2013) El Niño modulations over the past seven centuries. Nature Climate Change 3:1-5.

Malaize B, Bertran P, Carbonel P et al. (2011) Hurricanes and climate in the Caribbean during the past 3700 years BP. The Holocene 21: 911-924.

Malek EA (1969) Studies on 'Tropicorbid' snails (Biomphalaria: Planorbidae) from the Caribbean and Gulf of Mexico areas, including the southern United States. Malacologia 7: 183-209.

Malek EA (1985) Snail hosts of schistosomiasis and other snail-transmitted diseases in tropical America: A manual. Pan American Health Organization. Scientific Publication, No. 478.

Martens K and Behen F (1994) A checklist of the recent non-marine ostracods (Crustacea, Ostracoda) from the inland waters of South America and adjacent islands. Travaux Scientifiques du Musée national d'histoire naturelle de Luxembourg 22: 1-81.

McKillop WB and Harrison AD (1982) Hydrobiological studies of Eastern Lesser Antilles Islands, VII. St. Lucia: Behavioral drift and other movements of freshwater marsh molluscs. Archiv für Hydrobiologie 94: 53-69.

Muchmore WB (1993) List of terrestrial invertebrates of St. John, U.S. Virgin Islands (Exclusive of Acarina and Insects), with some records of freshwater species. Caribbean Journal of Science 29: 30-38.

Naranjo-Garcia E (1983) Nuevo registro y consideraciones morfológicas de Biomphalaria obstructa (Morelet, 1849) (Mollusca: Gastropoda) en México. Anales del Instituto de Biologia de la Universidad Nacional Autónoma de México 53:39-47.

Perera AAV, Noda JS, Jimenez YH (2010) Distribution and habitat preferences of the genus Biomphalaria (Gastropoda: Planorbidae) in Cuba. Memórias do Instituto Oswaldo Cruz, Rio de Janeiro 105: 41-44.

Pérez L, Lorenschat J, Brenner M (2010) Extant freshwater ostracodes (Crustacea: Ostracoda) from Lago Petén Itzá, Guatemala. Revista de Biología Tropicale 58: 871-895.
Pérez L, Curtis J, Brenner M et al. (2013) Stable isotope values $\left(\delta^{18} \mathrm{O} \&\right.$ $\delta 13 C$ ) of multiple ostracode species in a large Neotropical lake as indicators of past changes in hydrology. Quaternary Science Reviews 66: 96-111.

Peros MC, Reinhardt EG, Davis AM (2007) A 6000-year record of ecological and hydrological changes from Laguna de la Leche, north coastal Cuba. Quaternary Research 67: 69-82.

Rodgers EB, Adler RF, Pierce HF (2001) Contribution of tropical cyclones to the North Atlantic climatological rainfall as observed from satellites. Journal of Applied Meteorology 40: 1785-1800.

Sandberg PA (1964) The ostracod genus Cyprideis in the Americas. Acta Universitatis Stockholmiensis 12: 1-178.

Sars GO (1895) On some South-African "Entomostraca" raised from dried mud. Kongelige Dansk Videnskabernes Selskabs Skrifter Kjøbenhavn 8: 1-56.

Schlesinger ME, Ramankutty N (1994) An oscillation in the global climate system of period 65-70 years. Nature 367: 723-726.

Smith DG and Brousseau DJ (1996) Survey of the freshwater mollusks of St. John, U.S. Virgin Islands, with descriptions and anatomical details of two species. Caribbean Journal of Science 32: $33-$ 42.

Stephenson TS, Vincent LA, Allen T et al. (2014) Changes in extreme temperature and precipitation in the Caribbean region, 19612010. International Journal of Climatology 34: 2957-2971.

Stoddart D, Bryan G and Gibbs P (1973) Inland mangroves and water chemistry, Barbuda, West Indies. Journal of Natural History 7: 33-46.

Stuhlmann F (1888) Vorläufiger Bericht über eine mit Unterstützung der Königlichen Akademie der Wissenschaften unternommene Reise nach Ost-Africa zur Untersuchung der Süsswasserfauna. Sitzungsberichte der Königlich Preussischen Akademie der Wissenschaften zu Berlin 2: 1,255-1,269.

Taylor MA, Stephenson TS, Owino A et al. (2011) Tropical gradient influences on Caribbean rainfall. Journal of Geophysical Research 116: D00Q08.

Van Hengstum PJ, Donnelly JP, Toomey MR et al. (2014) Heightened hurricane activity on the Little Bahama Bank from 1350 to 1650 AD. Continental Shelf Research 86: 103-115.

Vásquez-Bedoya LF, Cohen AL, Oppo DW et al. (2012) Corals record persistent multidecadal SST variability in the Atlantic Warm Pool since 1775 AD. Paleoceanography 27: PA3231.

Wang C (2007) Variability of the Caribbean Low-Level Jet and its relations to climate. Climate Dynamics 29: 411-422.

Winter A, Christy J, Ishioroshi H et al. (2000) Caribbean Sea surface temperatures: Two-to-three degrees cooler than present during the Little Ice Age. Geophysical Research Letters 27: 3,365-3,368.

Winter A, Miller T, Kushnir Y et al. (2011) Evidence for 800 years of North Atlantic multi-decadal variability from a Puerto Rican speleothem. Earth and Planetary Science Letters 308: 23-28.

Wozniak A, Roman C, Wainright S et al. (2006) Monitoring food web changes in tide-restored salt marshes: A carbon stable isotope approach. Estuaries and Coasts 29: 568-578.

Yong M, Gutierrez A, Perera G et al. (2001) The Biomphalaria havanensis complex (Gastropoda: Planorbidae) in Cuba: A morphological and genetic study. Journal of Molluscan Studies 67: 103-111. 